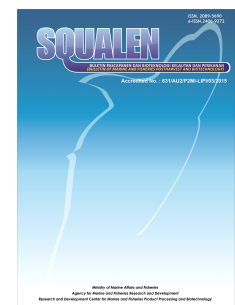

www.bbp4b.litbang.kkp.go.id/squalen-bulletin

Squalen Bulletin of Marine and Fisheries Postharvest and Biotechnology

ISSN: $2089-5690$

e-ISSN: 2406-9272

\title{
Genetic Diversity Analysis of Cultivated Kappaphycus in Indonesian Seaweed Farms using COI Gene
}

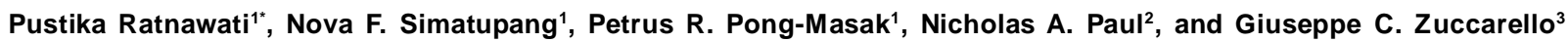 \\ 1) Research Institute for Seaweed Culture, Ministry of Marine Affairs and Fisheries, \\ Jl. Pelabuhan Etalase Perikanan, Boalemo, Gorontalo, Indonesia 96265 \\ 2) School of Science and Engineering, University of the Sunshine Coast, Sippy Downs, \\ Maroochydore DC, Australia 4556 \\ ${ }^{3}$ School of Biological Sciences, Victoria University of Wellington, Wellington, New Zealand 6140 \\ Article history: \\ Received: 20 May 2020; Revised: 20 July 2020; Accepted: 11 August 2020
}

\begin{abstract}
Indonesia is a major player in the aquaculture of red algae, especially carrageenan producing 'eucheumatoids' such as Kappaphycus and Eucheuma. However, many current trade names do not reflect the evolutionary species and updated taxonomy, this is especially the case for eucheumatoid seaweeds that are highly variable in morphology and pigmentation. Genetic variation is also not known for the cultivated eucheumatoids in Indonesia. Therefore, this study aimed to determine the species and the level of genetic variation within species of cultivated eucheumatoids from various farms across Indonesia, spanning 150-1500 km, using the DNA barcoding method. Samples of seaweed were randomly collected at 14 farmed locations between April 2017 and May 2018. For this study the 5prime end ( $600 \mathrm{bp}$ ) of the mitochondrial-encoded cytochrome oxidase subunit one (COI) was amplified and sequenced. Morphological examination showed that the samples were quite variable in branching pattern and color. All samples collected from farms with floating line cultivation were identified based on COI sequences as Kappaphycus alvarezii and showed no variation in the COI gene. One farm sample with bottom-line cultivation was identified as $K$. striatus. The low genetic variation is in contrast to the phenotypic variation of samples, indicating that variation and phenotypic responses to environments is still found in samples with implications for growth rates and carrageenan yield and quality. Information about the genetic variation in stocks is important base knowledge for maintaining, expanding and continuing seaweed aquaculture.
\end{abstract}

Keywords: COI, Indonesia, Kappaphycus, phylogeny, species identification

\section{Introduction}

Seaweed aquaculture is a relatively new but already a large and growing enterprise around the world (FAO, 2016). As with all new primary industries, many basic biological questions still need to be determined, including the nature of potential pathogens, the resilience of the cultivated species to perturbations, and methods to continually improve these crops. Equally important is the identification and potential genetic diversity of the species under cultivation. Indonesia is a major player in seaweed aquaculture, especially in the growth and production of carrageenan-producing red seaweeds, the eucheumatoids, including the genus Eucheuma and especially Kappaphycus.

In 1969, Kappaphycus was introduced in Indonesia and became known commercially as 'cottonii' in farms that were established in 1985 (Hurtado, Gerung, Yasir, \& Critchley, 2014; Hurtado, Reis, Loureiro, \& Critchley, 2014). Indonesia has more than 20 developed cultivation centers, with the main areas being in Sulawesi, Kalimantan, and Nusa Tenggara. Seaweed production in 2017 was 10.5 million tons and in 2018 was 10.35 million tons (wet weight) (Kementerian Kelautan dan Perikanan, 2019). Most of the seaweeds from cultivation are exported as raw material.

${ }^{*}$ Corresponding author.

E-mail: ratnawatipustika@gmail.com

Copyright @ 2020, Squalen BMFPB. Accreditation Number: 21/E/KPT/2018.

DOI: http://dx.doi.org/10.15578/squalen.v15i2.466 
Indonesian dried seaweed exports for 2017 was 173,624 tons and for 2018 was 192,276 tons (Badan Pusat Statistik, 2019).

The local production of seaweeds is accompanied by various trade names that do not reflect the evolutionary species, this is especially the case of the commercial red seaweeds that are highly variable in morphology. In Indonesia, the major seaweed crop is called 'cottonii', a name reflecting the previous taxonomic name Eucheuma cottonii Weber Bosse which has been synonymized to Kappaphycus alvarezii (Doty) Doty ex P.C. Silva (Doty, 1988; Silva, Basson, \& Moe, 1996). Another name used is 'sacol' for Kappaphycus striatus (F. Schmitz) Doty ex P.C. Silva (previously named Eucheuma striatum F. Schmitz). The difference between $K$. striatus and $K$. striatum is an artefact of some practitioners using the masculine or neutral species name. K. striatus is the accepted taxonomic name, with striatus meaning "striped" in Latin (Guiry \& Guiry, 2020).

A related genus is also cultivated in lesser amounts, i.e. Eucheuma denticulatum (N. L. Buman) Collins \& Hervey (previously named Eucheuma spinosum J. Agardh, trade name 'spinosum'). There were also variety of names that have been formally described relating to the name of collection sites or morphologies (e.g., tambalang, ajak-assi, maumere; Doty, 1988). The genetic distinctness, based on DNA mitochondrial and plastid gene or spacer sequences, of these varieties has been questioned (Zuccarello et al., 2006), and this variation may just reflect plasticity in particular environments or local selection.

Red algae are difficult to identify to species due to their extreme phenotypic plasticity and lack of, or difficulty in finding, diagnostic morphological characters (Verbruggen, 2014). Molecular methods have been proven to be a reliable method of identifying species and determining the level of genetic variation within species. The so-called DNA barcoding of species for molecular identification has been used extensively to identify species in red algae, to discover hidden species diversity (i.e. cryptic species) as well as to discover the levels and distribution of genetic variation in habitats (Muangmai, Fraser, \& Zuccarello, 2015).

The genetic diversity, relatedness and phylogeny of eucheumatoids have been studied extensively (Zuccarello et al., 2006; Tan, Lim, \& Phang, 2013; Tan et al., 2012; Dumilag, Orosco, \& Lluisma, 2016), using both mitochondrial and plastid DNA markers. The earliest publication showed that both mitochondrial and plastid markers clearly separated the genera Eucheuma and Kappaphycus from each other and separated species within these two genera
(Zuccarello et al., 2006). This study used the Rubisco spacer, an approximately $300 \mathrm{bp}$ fragment that contains the short segment ( 3 prime end) of the $r b c L$ gene and the spacer between $r b c L$ and $r b c S$ plus a portion ( 5 prime end) of the neighboring rbcS gene. The mitochondrial marker used was the spacer between the cytochrome oxidase subunit 2 (COX2) and subunit 3 (COX3), this marker is also about 350 bp in length. This study also showed that in cultivation, for the majority of samples, only one mitochondrial genotype was found throughout the world.

Partial mitochondrial cytochrome oxidase subunit I gene (COI-5P) is commonly used for identifying species (Hebert, Cywinska, Ball, \& deWaard, 2003), and is longer than the previously mentioned markers ( $600 \mathrm{bp}$ ). The COI marker is widely used for Kappaphycus identification for taxonomic purposes and phylogenetic relationships (Tan, Lim, \& Phang, 2013). The COI marker of red algae for this gene is very robust and it has greater variation than the COX2COX2 spacer in eucheumatoids (Dumilag et al., 2018; Dumilag \& Aguinaldo, 2017). Identification of Kappaphycus using $\mathrm{COI}$ has been performed in several countries: Hawaii (Conklin, Kurihara, \& Sherwood, 2009), Malaysia (Tan, Lim, \& Phang, 2013), and the Philipppines (Dumilag, Orosco, \& Lluisma, 2016).

Follow up studies in several countries also showed that cultivated genotypes have been colonized, and even have been replacing wild genotypes in noncultivated habitats (Halling et al., 2013; Tano, Halling, Lind, Buriyo, \& Wikström, 2015; Dumilag, Orosco, \& Lluisma, 2016). It is clear that molecular methods can aid in determining species of red algae, however, these methods have not been extensively applied to cultivated eucheumatoids or 'cottonii' in Indonesia. Therefore, an unequivocal identification of the species in production is still not known, nor is the genetic variation in cultivation farms. This study, therefore, aims to determine the species used in cultivation from various farms across Indonesia.

\section{Material and Methods}

\subsection{Sample Collections}

Samples were randomly collected in 14 farmed locations from western Indonesia (Sumatra) to eastern Indonesia (Maluku) between April 2017 and May 2018 (Table 1). Determination of the location as a representative of the cultivation centers was based on recommendations from the local government. Approximately $2 \mathrm{~cm}$ of the algal apical axes were placed in ample silica gel in ziplock bags for DNA preservation. 


\subsection{DNA extraction}

DNA was extracted from $0.5 \mathrm{~g}$ of apical tips using a modified CTAB method (Zuccarello \& Lokhorst, 2005; Zuccarello \& Paul, 2019), including proteinase $\mathrm{K}(4 \mu \mathrm{g})$ in the lysis buffer. Precipitated DNA was dissolved in $50 \mu \mathrm{L}$ of $0.1 \mathrm{X}$ TE $(10 \mathrm{mM}$ Tris, $0.1 \mathrm{mM}$ EDTA). The 5-prime end, $600 \mathrm{bp}$, of the mitochondrialencoded COI was amplified using the following PCR mix. A $20 \mu \mathrm{L}$ of PCR volume containing: 1X buffer, 2.5 $\mathrm{mM} \mathrm{MgCl}, 0.2 \mathrm{mM}$ dNTPs, $0.5 \%$ bovine serum albumin (BSA), $1 \cup$ Taq polymerase (Vivantis, Selangor Darul Ehsan, Malaysia) and $7.5 \mathrm{pmol}$ of the COI primers using GazF1 (5' TCAACAAATCATAAAGATATTGG 3') and GazR1 (5' ACTTCTGGATGTCCAAAAAAYCA 3') (Saunders, 2005).

The PCR cycling conditions were: an initial denaturing at $94^{\circ} \mathrm{C}$ for $5 \mathrm{~min}$; followed by 35 cycles of $95^{\circ} \mathrm{C}$ for $30 \mathrm{~s}, 45^{\circ} \mathrm{C}$ for $1 \mathrm{~min}$ and $72^{\circ} \mathrm{C}$ for $1 \mathrm{~min}$, and a final elongation step of $72^{\circ} \mathrm{C}$ for $5 \mathrm{~min}$. PCR products were checked for quality and quantity using $1 \%$ agarose gel electrophoresis. PCR products were commercially purified and Sanger sequenced at $1^{\text {st }}$ BASE (Singapore).

\subsection{Phylogeny and DNA Diversity Measurement}

Samples were sequenced in both directions using the amplification primers. Sanger sequence traces were assembled, edited and extracted to an alignment in Geneious Prime (https://www.geneious.com). COI sequences of various haplotypes (sequence variants) and species of Kappaphycus were also downloaded from National Center of Bioinformatics Institute (NCBI) (https://www.ncbi.nlm.nih.gov/) and added to the alignment. Alignment was done using ClustalW, no indel were observed in the alignment.

A maximum-likelihood analysis was implemented using IQ-tree (Trifinopoulos, Nguyen, Haeseler, \& Minh, 2016). IQ-tree was used to select the molecular evolution model for each codon position (Modelfinder) and construct a maximum-likelihood (ML) trees with 500 bootstrap approximations. A divergent sequence of Kappaphycus (Kappaphycus sp. VYT 2013a, GenBank Accession Number KC192782) was used as an outgroup. Base pair differences between samples were determined using MEGA6 (www. megasoftware.net) (Tamura, Stecher, Peterson, Filipski, \& Kumar, 2013) .

\section{Results and Discussion}

\subsection{Morphology of Seaweed}

Samples were collected from floating lines throughout Indonesia (Table 1), plus a single sample from a bottom-line farm in Poto Tano, West Nusa Tenggara. Floating line samples were quite variable in morphology (branching pattern and color). Generally, observation of morphology showed three types of color variation: brown (Pangkep, Bontang, Bantaeng, Lombok, Mamuju, Sumbawa, Maumere), red-brown (Manado, Kupang, Banten, Gorontalo, Saumlaki, Tual) and green-brown (Lampung) with many branches (Figure 1). The samples from Sumatra, West Nusa Tenggara and Java have brown color with many branches and small thalli, different from those collected in Sulawesi and Maluku, which have brown and red-brown color with a large thallus and many branches.

Strains from Lampung are a known tissue culture variant that has been widely developed by the farmers. Previous studies on $K$. alvarezii and color variation from several areas in Malaysia, have also found a range of colors from brown, green, to yellow and pink (Tan, Lim, \& Phang, 2013). Sample from Sumbawa, West Nusa Tenggara was identified as $K$. striatus with green color and compact thalli (Figure 2; Table 1). $K$. striatus or sacol (Dumilag, Orosco, \& Lluisma, 2016; Ask \& Azanza, 2002) is a seaweed that is generally cultivated in this area. $K$. striatus generally has green and yellow-green color with dense and compact thalli, giving a cauliflower-like appearance; the surface was smooth and cartilaginous, and had occasional blunt protrusions (Tan, Lim, \& Phang, 2013).

\subsection{Analysis of DNA Sequences}

PCR amplification was successful after various DNA dilutions (up to 100 -fold). The edited sequences were aligned to a COI data set consisting of multiple species and isolates of Kappaphycus (K. alvarezii, K. malensiaus, $K$. striatus) downloaded from NCBI GenBank (Figure 2). The aligned dataset was 627 bases long. The molecular evolution models used for the maximum-likelihood tree $\left(1^{\text {st }}\right.$ codon position= $\mathrm{K} 2 \mathrm{P}+\mathrm{I} ; 2^{\text {nd }}$ codon $=\mathrm{F} 81+\mathrm{F} ; 3^{\text {rd }}$ codon $=\mathrm{HKY}+\mathrm{F}$ ) produced a phylogeny with a log likelihood score of 1342.6655 (Figure 2). All samples from floating lines (1-13) were identified based on $\mathrm{COI}$ sequences as $K$. alvarezii and grouped with other $K$. alvarezii samples (Figure 2; Table 1).

K. alvarezii from all samples also had identical haplotypes (no sequence variation), which was identical to the major cultivated haplotype (GenBank accession number KT316556) Dumilag et al., 2016) (Table 1). The bottom-line sample (14) was identified using $\mathrm{COI}$ sequences as $\mathrm{K}$. striatus (Figure 2; Table 1). There were 27 basepair differences (4\%) between the $\mathrm{COI}$ sequence of samples of $K$. alvarezii and that of $K$. striatus from Indonesia. 
Table 1. Identification of samples using COI gene

\begin{tabular}{|c|c|c|c|c|c|c|}
\hline No. & $\begin{array}{l}\text { Sample } \\
\text { name }\end{array}$ & Location & GPS coordinates & $\begin{array}{l}\text { Date of } \\
\text { collection }\end{array}$ & $\begin{array}{c}\text { Sample } \\
\text { identification }\end{array}$ & $\begin{array}{c}\text { COI haplotype } \\
\text { (GenBank accession } \\
\text { number) }\end{array}$ \\
\hline 1 & Pangkep & $\begin{array}{l}\text { Boddie, Pangkep, South } \\
\text { Sulawesi }\end{array}$ & $\begin{array}{l}\text { S } 4^{\circ} 35^{\prime} 45.42^{\prime \prime}, \\
\text { E } 119^{\circ} 24^{\prime} 55^{\prime \prime}\end{array}$ & May, 2017 & K. alvarezii & KT316556 \\
\hline 2 & Bontang & Bontang, East Kalimantan & $\begin{array}{l}\text { N 007'37.28", } \\
\text { E 117 } 31^{\circ} 35.35^{\prime \prime}\end{array}$ & May, 2017 & K. alvarezii & KT316556 \\
\hline 3 & Bantaeng & Bantaeng, South Sulawesi & $\begin{array}{l}\text { S 5 } 5^{\circ} 29^{\prime} 32.82 " \\
\text { E } 119^{\circ} 54^{\prime} 12.36^{\prime \prime}\end{array}$ & May, 2017 & K. alvarezii & KT316556 \\
\hline 4 & Manado & $\begin{array}{l}\text { Kulu, North Minahasa, Manado, } \\
\text { North Sulawesi }\end{array}$ & $\begin{array}{l}\text { N 1 } 1^{0} 41^{\prime} 43.02^{\prime \prime}, \\
\text { E 124'57'19.98" }\end{array}$ & May, 2017 & K. alvarezii & KT316556 \\
\hline 5 & Lombok & $\begin{array}{l}\text { Serewe, East Lombok, West } \\
\text { Nusa Tenggara }\end{array}$ & $\begin{array}{l}\text { S 8 } 54^{\prime} 1.75^{\prime \prime}, \\
\text { E116 } 30^{\prime} 41.04^{\prime \prime}\end{array}$ & May, 2017 & K. alvarezii & KT316556 \\
\hline 6 & Banten & Tirtayasa, Serang, Banten & $\begin{array}{l}S 5^{\circ} 57^{\prime} 49.09 \prime \\
E 106^{\circ} 17^{\prime} 48.678^{\prime \prime}\end{array}$ & April, 2017 & K. alvarezii & KT316556 \\
\hline 7 & Kupang & Kupang, East Nusa Tenggara & $\begin{array}{l}\text { S } 10^{\circ} 9^{\prime} 1,81^{\prime \prime} \\
\text { E } 123^{\circ} 32^{\prime}, 31^{\prime \prime}\end{array}$ & May, 2017 & K. alvarezii & KT316556 \\
\hline 8 & Gorontalo & $\begin{array}{l}\text { Langge, North Gorontalo, } \\
\text { Gorontalo }\end{array}$ & $\begin{array}{l}\text { N } 0^{\circ} 48^{\prime} 57^{\prime \prime} \\
\text { E } 122^{\circ} 50^{\prime} 52^{\prime \prime}\end{array}$ & May, 2017 & K. alvarezii & KT316556 \\
\hline 9 & Mamuju & Mamuju, West Sulawesi & $\begin{array}{l}\text { S 2 }{ }^{\circ} 37^{\prime} 55.43^{\prime \prime}, \\
E 118^{\circ} 57^{\prime} 38.86^{\prime \prime}\end{array}$ & April, 2017 & K. alvarezii & KT316556 \\
\hline 10 & Lampung & $\begin{array}{l}\text { South Lampung, Lampung, } \\
\text { Sumatra }\end{array}$ & $\begin{array}{l}S 5^{\circ} 43^{\prime} 84^{\prime \prime} \\
\text { E } 105^{\circ} 47^{\prime} 898^{\prime \prime}\end{array}$ & May, 2017 & K. alvarezii & KT316556 \\
\hline 11 & Saumlaki & $\begin{array}{l}\text { Saumlaki, Southeast west } \\
\text { Maluku, Maluku }\end{array}$ & $\begin{array}{l}\text { S } 7^{\circ} 58^{\prime} 51^{\prime \prime} \\
\text { E } 131^{\circ} 17^{\prime} 46^{\prime \prime}\end{array}$ & May, 2018 & K. alvarezii & KT316556 \\
\hline 12 & Maumere & $\begin{array}{l}\text { Kojadoi, Sikka Maumere, East } \\
\text { Nusa Tenggara }\end{array}$ & $\begin{array}{l}\text { S 8 }{ }^{\circ} 29^{\prime} 39.7^{\prime \prime} \\
\text { E } 122^{0} 24^{\prime} 4,4^{\prime \prime}\end{array}$ & May, 2018 & K. alvarezii & KT316556 \\
\hline 13 & Tual & $\begin{array}{l}\text { Tual, Southeast Maluku, } \\
\text { Maluku }\end{array}$ & $\begin{array}{l}S 5^{\circ} 40^{\prime} 12^{\prime \prime} \\
E 132^{\circ} 44^{\prime} 56^{\prime \prime}\end{array}$ & May, 2018 & K. alvarezii & KT316556 \\
\hline 14 & Sumbawa & $\begin{array}{l}\text { Poto Tano, Sumbawa, West } \\
\text { Nusa Tenggara }\end{array}$ & $\begin{array}{l}S 8^{0} 42^{\prime} 27,7^{\prime \prime}, \\
\text { E } 116^{\circ} 46^{\prime} 32,9^{\prime \prime}\end{array}$ & May, 2018 & K. striatus & KC192776 \\
\hline
\end{tabular}

While the carrageenan industry in Indonesia has expanded immensely, an accurate identification of the carragenan-producing algae in cultivation is often missing. This study sampled eucheumatoids across the expanse of Indonesia and cultivation areas and shows that crops of 'cottonii' (Hurtado et al., 2014; Ask \& Azanza, 2002) were all belong to the species $K$. alvarezii. This study also shows that genetic variation, as measured in mitochondrial $\mathrm{COI}$ haplotypes, is limited in the cultivated $K$. alvarezii in Indonesia.

This low genetic variation in cultivation has already been reported (Zuccarello et al., 2006; Dumilag, Salvador \& Halling, 2016) and is believed to be due to the clonal (fragmentation) method of cultivation and transportation around the country and the world. The world-wide cultivated haplotype was determined using the mitochondrial COX2-COX3 spacer (Zuccarello et 

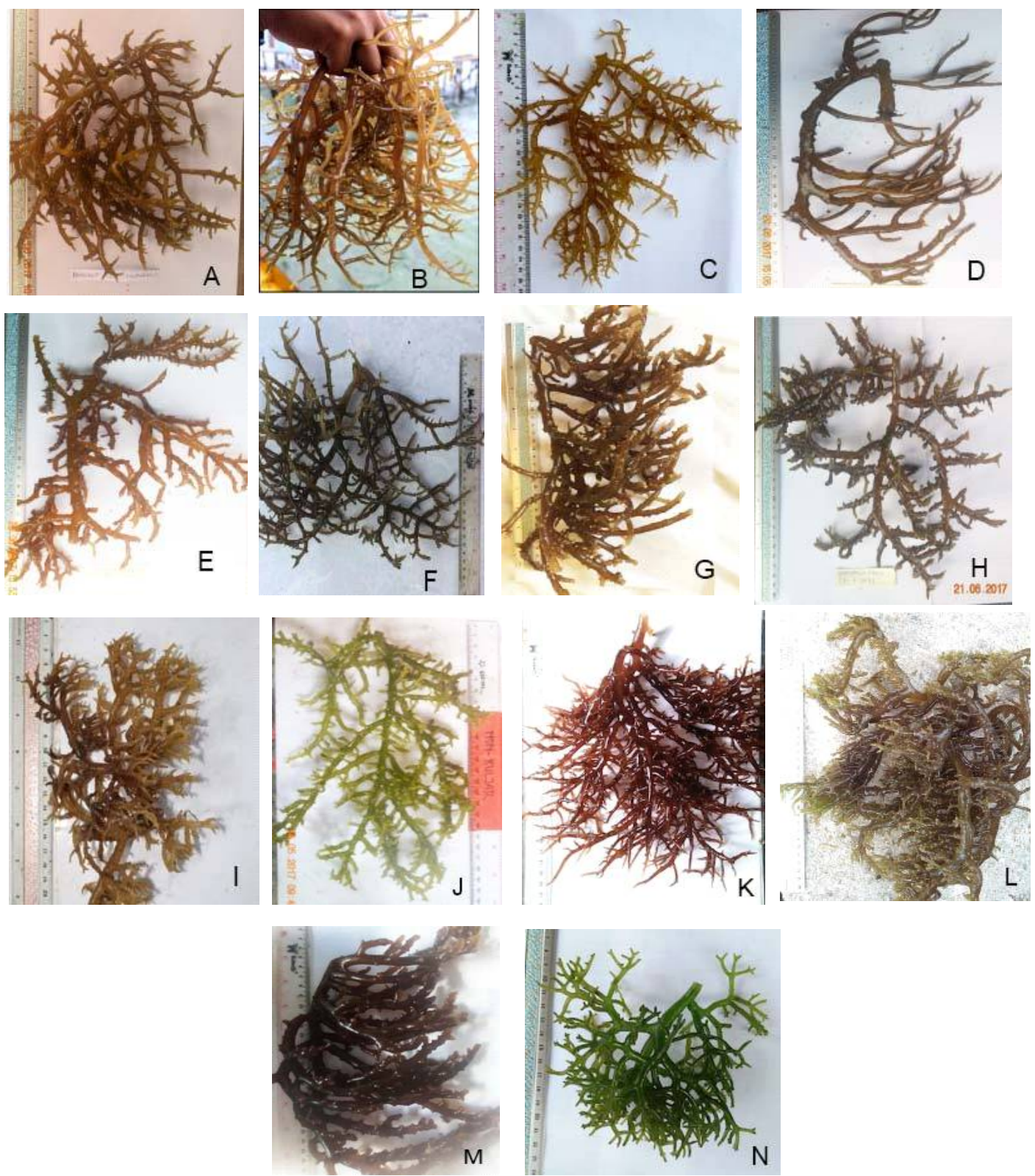

Figure 1. Morphological and color variation in samples collected around Indonesia. $A=$ Pangkep (South Sulawesi), $B=$ Bontang (East Kalimantan), $C=$ Bantaeng (South Sulawesi), $D=$ Manado (North Sulawesi), $E=$ Lombok (West Nusa Tenggara), F= Banten, G= Kupang (East Nusa Tenggara), H= Gorontalo, I= Mamuju (West Sulawesi), J= Lampung, K= Saumlaki (Southeast West Maluku), L= Maumere (East Nusa Tenggara), $M=$ Tual (Southeast Maluku), $N=$ Sumbawa (West Nusa Tenggara).

al., 2006) and was designated as E3. This E3 haplotype is also found in plants with the KALV COI haplotype (GenBank accession number KT316556) (Dumilag et al., 2016), the haplotype found in all Indonesian $K$. alvarezii examined in this study.

Information about genetic variation is an important factor in maintaining, expanding and continuing seaweed aquaculture. Based on COI haplotypes, this study showed that variation in the Indonesian strains of Kappaphycus is very low in cultivation, including samples acclimated and under cultivation at scale across a broad range of sites that have been propagated from fragmentation or tissue culture. The low genetic variation in Kappaphycus is in contrast to the phenotypic variation of samples, indicating that genetic variation, and phenotypic responses to environments is still found in samples but cannot be identified using the $\mathrm{COI}$ marker. We recommend that native genetic variants be looked for in Indonesia to diversify the genetic stock across the country. These 


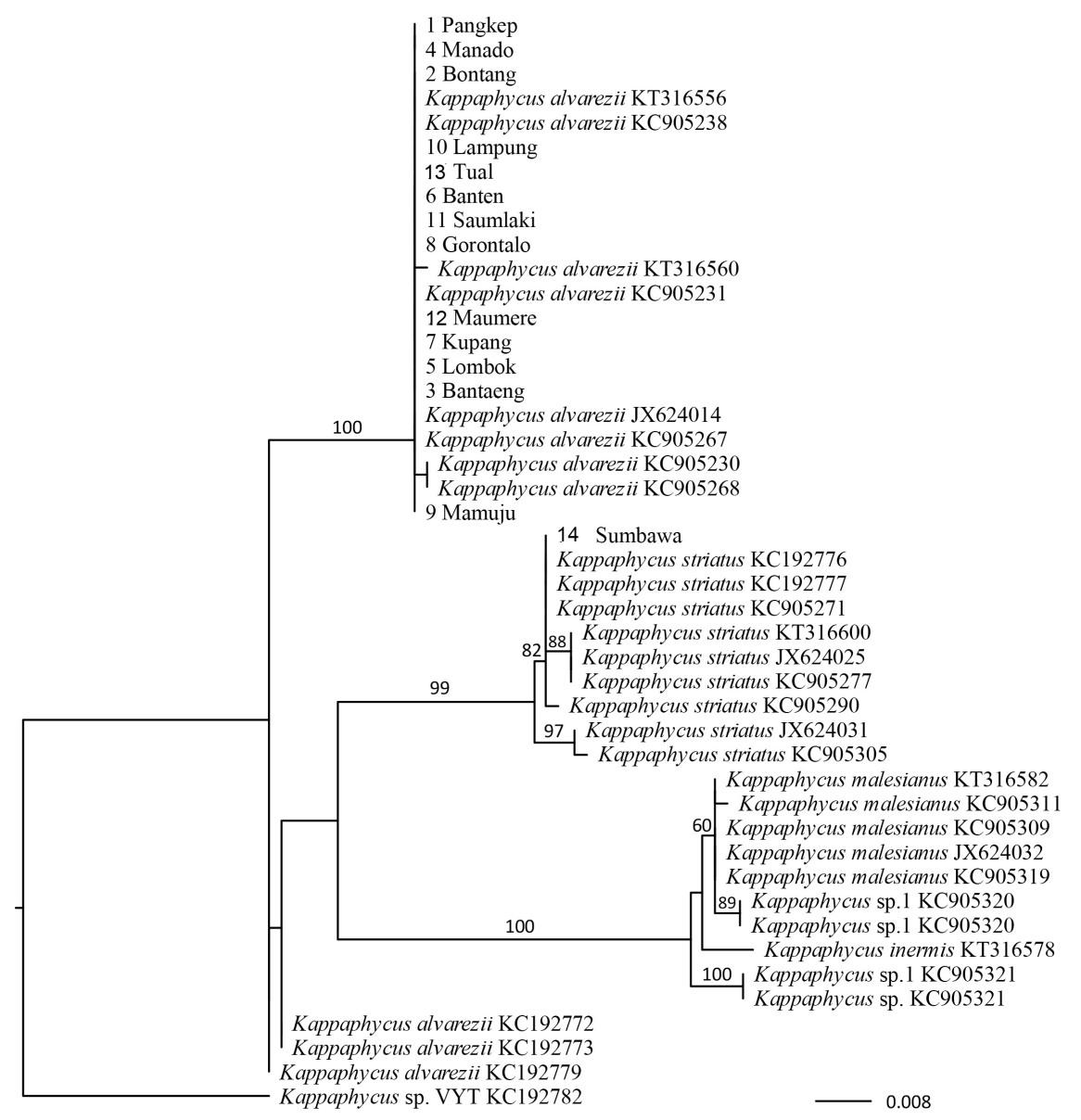

Figure 2. Maximum-likelihood phylogeny of partial COI DNA sequences of Kappaphycus samples from around Indonesia plus identified sequences from GenBank with their accession numbers. Indonesian sequences were mostly $K$. alvarezii, plus one $K$. striatus. Scale bar = substitution/site

variants should be tested for useful aquaculture and carrageenan gel traits.

\section{Conclusion}

Our study revealed that $K$. alvarezii from floating lines on farms across Indonesia was identical to the major cultivated haplotype (GenBank accession number KT316556) based on COI sequences. Species from bottom-line sample was identified as $K$. striatus using $\mathrm{COI}$ sequences. There was no variation in the cultivated Indonesian strains of $K$. alvarezii used in this study. This finding was in contrast to the phenotypic variation of samples. These results indicated that phenotypic responses to environments and underlying genetic factors are still found in samples. This has implications for growth rates as well as carrageenan yield and quality in these samples in Indonesia.

\section{Acknowledgments}

We thank the staffs of the Research Institute for Seaweed Culture Gorontalo for their assistance with this study: Twynnugroho H. Wiyanto, Dwi Ayu Purwanti, Elmiwia R. Baturante, Handy Burase, and Restu Randing. Head of the biotechnology laboratory Dr. Andi Parenrengi from the Research Institute for Coastal Aquaculture and Fisheries Extension Maros, South Sulawesi. This research was supported by the Australian Centre for International Agricultural Research (ACIAR) under project FIS/2015/038 'Improving seaweed production and processing opportunities in Indonesia'.

\section{References}

Ask, E. I., \& Azanza, R.V. (2002). Advances in cultivation technology of commercial eucheumatoid species: a 
review with suggestions for future research. Aquaculture, 206, 257-277. doi: 10.1016/S00448486(01)00724-4.

Badan Pusat Statistik. (2019). Ekspor rumput laut dan ganggang lainnya menurut negara tujuan utama tahun 2012-2018. Retrieved from www.bps.go.id/ statictable/2019/02/25/2025/ekspor-rumput-lautdan-ganggang-lainnya-menurut-negara-tujuanutama-2012-2018.html. Accessed on March 2020.

Conklin, K. Y., Kurihara, A., \& Sherwood, A. R. (2009). A molecular method for identification of the morphologically plastic invasive algal genera Eucheuma and Kappaphycus (Rhodophyta, Gigartinales) in Hawaii. Journal of Applied Phycology, 21(6), 691-699. doi: 10.1007/s10811-009-9404-2.

Doty, M. S. (1988). Prodomus ad systematica eucheumatioderum: A tribe of commercial seaweeds related to Eucheuma (Solieiriaceae, Gigartinales). In Abbott, I. A. [Ed.] Taxonomy of Economic Seaweeds. California Sea Grant Program, La Jolla, California, 159-207.

Dumilag, R.V., Orosco, F.L. \& Lluisma, A.O. (2016). Genetic diversity of Kappaphycus species (Gigartinales, Rhodophyta) in the Philippines. Systematics and Biodiversity, 14, 441-451. doi: 10.1080/14772000.2016.1157643.

Dumilag, R.V., Salvador, R.C. \& Halling, C. (2016). Genotype introduction affects population composition of native Philippine Kappaphycus (Gigartinales, Rhodophyta). Conservation Genetics Resources, 8, 439-441. doi: 10.1007/s12686-016-0591-2.

Dumilag, R. V., \& Aguinaldo, Z. Z. A. (2017). Genetic differentiation and distribution of Pyropia acanthophora (Bangiales, Rhodophyta) in the Philippines. European Journal of Phycology, 52(1), 104-115. doi: 10.1080/09670262.2016.1230786.

Dumilag, R.V., Gallardo, W.G.M., Garcia, C.P.C., You, Y., Chaves, A.K.G. \& Agahan, L. (2018). Phenotypic and mtDNA variation in Philippine Kappaphycus cottonii (Gigartinales, Rhodophyta). Mitochondrial DNA Part A DNA Mapping, Sequensing, and Analysis. 29: 95163. doi: 10.1080/24701394.2017.1398745.

FAO (2016). The State of World Fisheries and Aquaculture 2016 - Contributing to food security and nutrition for all. FAO Rome, Italy.

Guiry, M.D., \& Guiry, G.M. (2020). AlgaeBase. World-wide electronic publication, National University of Ireland, Galway. Retrieved from www.algaebase.org/search/ species/detail/? species_id=2814\&session=abv4:AC1F117B13e0c2EDBAnhE5E0E335. Accessed on 14 August 2020.

Halling, C., Wikström, S.A., Lilliesköld-Sjöö, G., Mörk, E., Lundsør, E. \& Zuccarello, G.C. (2013). Introduction of Asian strains and low genetic variation in farmed seaweeds: indications for new management practices. Journal of Applied Phycology, 25, 89-95. doi: 10.1007/s10811-012-9842-0.

Hebert, P. D. N., Cywinska, A., Ball, S. L., \& deWaard, J. R. (2003). Biological identifications through DNA barcodes. Proceedings of the Royal Society $B$ : Biological Sciences, 270(1512), 313-321. doi: 10.1098/rspb.2002.2218.

Hurtado, A. Q., Gerung G. S., Yasir S., \& Critchley, A.T. (2014). Cultivation of tropical red seaweeds in the BIMP-EAGA Region. Journal of Applied Phycology, 26, 707-718. doi: 10.1007/s10811-013-0116-2.

Hurtado, A. Q., Reis, R. P., Loureiro, R. R., \& Critchley, A. T. (2014). Kappaphycus (Rhodophyta) Cultivation: Problems and the Impacts of Acadian Marine Plant Extract Powder. In Marine Algae: Biodiversity, Taxonomy, Environmental Assessment, and Biotechnology. Portugal : University of Coimbra. doi: 10.1201/b17540-9.

Kementerian Kelautan dan Perikanan. (2019). Statistik produksi perikanan komoditas rumput laut tahun 2017-2018. Retrieved from statistik.kkp.go.id/ home.php? $m=$ total\& $\mathrm{i}=2 \#$ panel-footer. Accessed on March 2020.

Muangmai, N., Fraser, C., \& Zuccarello, G.C. (2015). Contrasting patterns of population structure and demographic history in cryptic species of Bostrychia intricata (Rhodomelaceae, Rhodophyta) from New Zealand. Journal of Phycology, 51, 574-585.doi: 10.1111/jpy. 12305.

Saunders, G. (2005). Applying DNA barcoding to red macroalgae: a preliminary appraisal holds promise for future applications. Philosophical Transactions of The Royal Society B: Biological Sciences, 360, 18791888. doi: $10.1098 /$ rstb.2005.1719.

Silva, P.C., Basson, P.W. \& Moe, R.L. (1996). Catalogue of the Benthic Marine Algae of the Indian Ocean. University of California Press, Oakland, CA, USA. 79, $1-1280$.

Tamura, K., Stecher, G., Peterson, D., Filipski, A., \& Kumar, S. (2013). MEGA6: molecular evolutionary genetics analysis version 6.0. Molecular Biology And Evolution, 30, 2725-2729. doi: 10.1093/molbev/ mst197.

Tan, J., Lim, P.-E., Phang, S.-M., Hong, D.D., Sunarpi, H. \& Hurtado, A.Q. (2012). Assessment of four molecular markers as potential DNA barcodes for red algae Kappaphycus Doty and Eucheuma J. Agardh (Solieriaceae, Rhodophyta). PLoS ONE, 7(12), 1-12. doi:10.1371/journal.pone.0052905.

Tan, J., Lim, P.E., \& Phang, S.-M. (2013). Phylogenetic relationship of Kappaphycus Doty and Eucheuma J. Agardh (Solieriaceae, Rhodophyta) in Malaysia. Journal of Applied Phycology, 25, 13-29. doi: 10.1007/ s10811-012-9833-1.

Tano, S.A., Halling, C., Lind, E., Buriyo, A. \& Wikström, S.A. (2015). Extensive spread of farmed seaweeds causes a shift from native to non-native haplotypes in natural seaweed beds. Marine Biology, 162, 198392. doi: 10.1007/s00227-015-2724-7.

Trifinopoulos, J., Nguyen, L.-T., Haeseler, V. A. \& Minh, B.Q. (2016). W-IQ-TREE: a fast online phylogenetic tool for maximum likelihood analysis. Nucleic Acids Research, 44, W232-5. doi: 10.1093/nar/gkw256. 
Verbruggen, H. (2014). Morphological complexity, plasticity, and species diagnosability in the application of old species names in DNA-based taxonomies. Journal of Phycology, 50, 26-31. doi: $10.1111 /$ jpy. 12155.

Zuccarello, G., Critchley, A., Smith, J., Sieber, V., Lhonneur, G. \& West, J. (2006). Systematics and genetic variation in commercial shape Kappaphycus and shape Eucheuma (Solieriaceae, Rhodophyta). Journal of Applied Phycology, 18, 643-651. doi: 10.1007/s10811-006-9066-2.
Zuccarello, G.C. \& Lokhorst, G.M. (2005). Molecular phylogeny of the genus Tribonema (Xanthophyceae) using $r b c L$ gene sequence data: monophyly of morphologically simple algal species. Phycologia, 44, 384-392. doi: 10.2216/0031-8884(2005) 44[384:MPOTGT]2.0.CO;2.

Zuccarello, G.C. \& Paul, N.A. (2019). A beginner's guide to molecular identification of seaweed. Squalen Bulletin for Marine and Fiheries Postharvest and Biotechnology, 14, 43-53. doi: 10.15578/ squalen.v14i1.384. 